\title{
Increase of Seismic Risk for Growth of a Large Metropolitan Area of Granada (Spain): Case Studies
}

\author{
I. Valverde-Palacios ${ }^{1} \&$ I. Valverde-Espinosa ${ }^{1}$ \\ ${ }^{1}$ Department of Building Construction, Escuela Técnica Superior de Arquitectura, University of Granada, \\ Granada, Spain \\ Correspondence: I. Valverde-Palacios, Department of Building Construction, Escuela Técnica Superior de \\ Arquitectura, University of Granada, Campus de Fuentenueva s/n 18071, Granada, Spain. Tel: 34-958-243-126. \\ E-mail: nachoval@ugr.es
}

Received: January 16, 2012 Accepted: February 1, 2012 Online Published: July 6, 2012

doi:10.5539/esr.v1n2p171

URL: http://dx.doi.org/10.5539/esr.v1n2p171

\begin{abstract}
This paper analyzes the creation, consolidation, and growth of the metropolitan area of the city of Granada (Spain) from 1956 to 2007, using GIS and aerial photographs. In the last fifty years, the population of Granada and its metropolitan area has doubled. This has led to an increase in built-up land of approximately 4650 ha. Furthermore, the areas that have experienced the largest growth in population and built-up land are located less than $15 \mathrm{~km}$ from the city. The consolidation of the metropolitan area (MA) in Granada began in the 1970s. In 1950-2009, the overall population density $\left(\mathrm{hab} / \mathrm{km}^{2}\right)$ rose $65 \%$. This study has provided support to the main investigation to justify the increase of the exposed elements since the MA of Granada is the most active seismic zone in Spain. This primary research examines the foundations of buildings in static and dynamic conditions and the best direction of growth of villages taking into account the soil characteristics. It was found that seismic risk in this area has increased because of the significant growth of the elements exposed at risk (number of buildings as well as population). This study shows that in some cases the growth directions are not correct.
\end{abstract}

Keywords: Metropolitan Area (MA), Granada (Spain), built-up land, population, GIS, earthquakes, density, seismic risk

\section{Introduction}

This paper documents and analyzes the creation, consolidation and growth of the metropolitan area of the city of Granada (Spain) from 1956 to 2007 with GIS and aerial photographs (Figure 1). In the last fifty years, the population of Granada and its metropolitan area has doubled. This has led to an increase in built-up land of approximately 4650 ha. Furthermore, the areas that have experienced the largest growth in population and built-up land are located less than $15 \mathrm{~km}$ from the city.

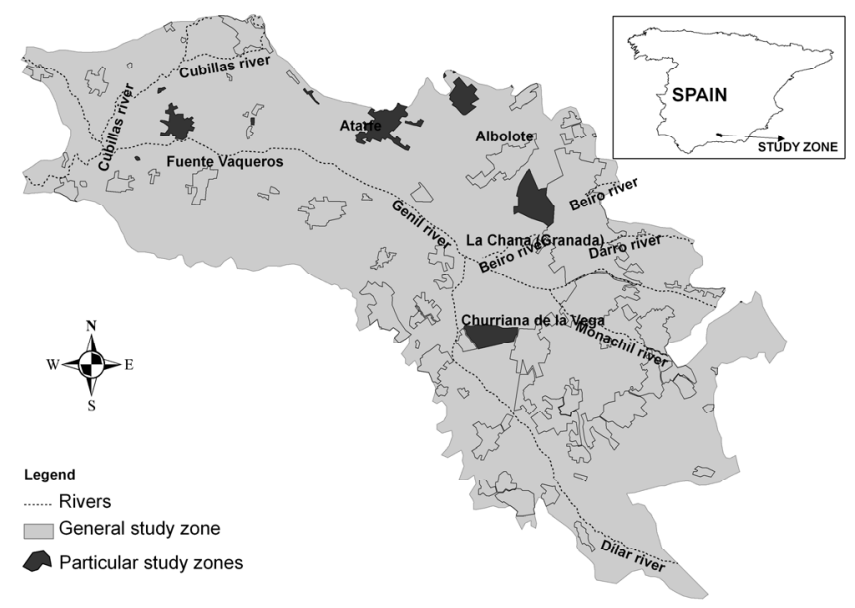

Figure 1. Location of the study zone 
This purpose of this analysis was to verify the risk of seismic events since the area of study is the most active seismic zone in Spain, according to the Spanish seismic code (NCSE-02). In fact, seismic risk in this area has increased because of the significant growth in the number of buildings and population. This is despite the fact that buildings are now less vulnerable to earthquakes because of technical advances in construction, new materials, energy dissipation, and regulations to minimize and mitigate construction vulnerability (Valverde-Palacios, 2010).

Because of its morphological and productive characteristics, the region of La Vega in Granada has always been different from other neighboring areas. Since ancient times, its natural features and human activity have made it a unique agricultural space. At one time, its strategic position as a crossroads and its orographic singularity converged to transform it into the most important urban nucleus of Eastern Andalusia. However, it fell into decay because of the progressive migration of the population and economic activity towards coastal areas. The inland city of Granada has never been directly connected to the Mediterranean even though since ancient times the inhabitants have tried to devise an effective communication network, though with little success. It was necessary to wait until, the 20th century before these projects finally prospered. It was only then when a direct connection was established between the inland and the coastline. However, until the 20th century, Granada was economically isolated because it was located in an area of difficult accessibility, and thus, of low productivity. This was a major obstacle to the concentration of farming and agricultural activity that occurred between the 16th and 19th centuries to enrich other large cities in the region of Andalusia. Granada thus remained at the subsistence level.

After the Spanish Civil war, there was a period of economic stagnation that lasted for 25 years. In 1940-1960, the population of the city of Granada remained at 195,000 people. In contrast, the population of surrounding areas increased by 10,000 (from approximately 87,000 to 97,000 inhabitants). This ruralization process was inevitable because of the lack of supplies and urban jobs. Not surprisingly, in 1960 the province of Granada ranked fourth to last in national income per person. It was only surpassed by the provinces of Cordoba, Badajoz and Guadalajara (INE, 2009). Unwin (1996), Van Geffen (2003), Cooke and Marchant (2006), Boix (2007), Rozenfeld et al. (2008), Aguilera et al. (2009), and Storper (2010) also analyze the causes of the growth of metropolitan areas.

This organization of this article is as follows. Section 2 reviews the concept of metropolitan area (MA) from its origin in the United States (1850) to its appearance in Spain in 1960. Section 3 applies this concept to Granada, and provides a detailed justification of why Granada can be regarded as an MA. Section 4 explains the methodology used in the study, and section 5 presents the results of metropolitan growth in Granada, and analyzes the case studies of four municipalities. The final section gives the relevant conclusions that can be derived from this research.

\section{The Concept of Metropolitan Area (MA)}

The definition of metropolitan area (MA) is crucial to the study of urban growth. Evidently, the way that this concept is defined has a direct effect on the conclusions derived from the statistical distribution of urban activity. This term, metropolitan area, appeared for the first time in the USA in 1850, and is recorded in the 1910 census of the Federal Office. This office used the term in 1910 and 1920. Within the context of this definition, a metropolitan area was regarded as a large population nucleus of over 200,000 inhabitants, which was not included in the radius of influence of another large population. This area encompassed all territory within a distance of 10 miles from the core urban nucleus and with a minimum population density of 150 inhabitants per square mile (U.S. Census Bureau). This definition, however, is based solely on population criteria (Berry et al., 1968; Font, 1972, De Esteban, 1981).

This definition was subsequently modified to include new variables. This specification of the term permitted the elaboration of models based on an integrated system of functions. The concepts of Standard Metropolitan Area (SMA) and Standard Metropolitan Statistical Area (SMSA) appeared in 1950 and 1960, respectively. They have been the basic reference for many of the studies and analyses of metropolitan areas in North America and Europe (Nunes, 1986; Serra, 1991; Van Geffen, 2003).

According to Gohhen (1971), the criteria used to define metropolitan areas are the following: definitional criteria, population criteria, metropolitan criterion, and inclusion criteria. New criteria were proposed by Fox (1964), Friedman, et al. (1965), Berry (1973), Font (1972), Coombes, et al. (1978) and Hall and Hay (1980) which include economic and functional integration. Serra (1991) concludes that the definition of metropolis should be based on metropolitan intensity, i.e., a functional relationship between the main urban nucleus and secondary population nuclei. 
Early studies that identify MAs in Spain date back to 1960 and 1967 (Boix, 2007), and are the work of the Spanish Ministry of Housing (1965). They used the following criteria, based on Davis (1959): (i) the existence of an urban nucleus of at least 50,000 inhabitants; (ii) economic and social links between the urban nucleus and peripheral municipalities such that the minimum population of the total area is 100,000 .

In Spain, the Ministry of Housing has continued to define and specify metropolitan areas. The most recent samples of this work are the Atlases of 2000 and 2005, which define metropolitan area in terms of three basic criteria: (i) population size of the central urban nucleus; (ii) primacy of an open and diffuse urban nucleus; (ii) economic and social integration in a system of daily social interaction and relations. All of these aspects are ultimately an integral part of modern territorial dynamics.

\section{Definition of Metropolitan Area of Granada (Spain)}

In the region of Andalusia in southern Spain, the Andalusian Institute of Statistics defines an MA, as a polynuclear urban area that constitutes a unitary market of residence and work as well as a collective living space (Feria et al., 2005). For the specification of the boundaries of the metropolitan areas of Andalusia, the regional government uses the criterion of residence-work mobility, which includes the social and functional interdependence of the various towns that comprise it (Almoguera \& Ríos, 2008).

The delimitation of the MA of Granada (Table 1) has been the focus of numerous studies (Fernández Avidad, 1999; Conde, 1999; Cañete et al., 2005; Sánchez Gonález, 2005), given the wide range of criteria that can be considered. Authors such as Menor (1997) identify the region of Granada as an MA. This region meets a series of conditions and urban indicators that confirm the close relationship between Granada, the core urban nucleus, and various peripheral population centers. However, the authors of the Plan de Ordenación del Territorio de la Aglomeración Urbana de Granada (Spatial and Territorial Plan of the Urban Agglomeration of Granada) (POTAUG, 1999) examined a wide range of documents about the province of Granada, each of which gave a different specification of its metropolitan area.

Table 1. Summary of the number of municipalities that make up the metropolitan area of Granada and the region of Granada

\begin{tabular}{cccccccc}
\hline & $\begin{array}{c}\text { POTAUG, } \\
1999\end{array}$ & $\begin{array}{c}\text { New POTAUG } \\
\text { prevision }\end{array}$ & $\begin{array}{c}\text { Sánchez } \\
\text { González, 2005 }\end{array}$ & $\begin{array}{c}\text { Menor, } \\
1997\end{array}$ & $\begin{array}{c}\text { Cañete et al., } \\
2005\end{array}$ & $\begin{array}{c}\text { Fernandez } \\
\text { Avidad, 1997 }\end{array}$ & $\begin{array}{c}\text { Conde, } \\
1999\end{array}$ \\
\hline $\begin{array}{c}\text { Metropolitan } \\
\text { area }\end{array}$ & 32 & 51 & 37 & - & 32 & 42 & 26 \\
$\begin{array}{c}\text { Region of } \\
\text { Granada }\end{array}$ & - & - & - & 33 & - & - & - \\
\hline
\end{tabular}

After analyzing the documentation, the experts who elaborated the POTAUG (1999) decided that the following group of municipalities should be included within the urban agglomeration of Granada: Albolote, Alhendín, Armilla, Atarfe, Cájar, Cenes de la Vega, Cúllar Vega, Churriana de la Vega, Granada, Huétor Vega, Jun, Las Gabias, La Zubia, Maracena, Monachil, Ogíjares, Peligros, Pulianas, and Vegas del Genil. This area was subsequently expanded to encompass Güevéjar, Víznar, and Alfacar because of their radial relationship with Granada, the main urban nucleus. .Pinos Genil was included since it was located in the corridor to the Sierra Nevada ski resort. Gójar and Otura were also regarded as part of the metropolitan area, and Gojar itself, as the nucleus for other smaller population centers. The towns of Chauchina, Fuente Vaqueros, Pinos Puente and Santa Fe were added to the MA because of their central location in La Vega of Granada. Finally, Cijuela, Dilar, and Láchar were also included because of their functional relationship with the other municipalities in the metropolitan area.

Fernández Avidad (1997) defines, an MA, based on the criteria specified in Spanish Metropolitan Areas (Ministerio de Vivienda, 1960). According to these criteria, Granada can effectively be regarded as a metropolitan area.

Total population in the area of more than $\mathbf{1 0 0 , 0 0 0}$ inhabitants. There are 500,469 inhabitants in the MA of Granada (INE, 2009).

An industrial workforce of over 20,000 inhabitants in each municipality. In the city of Granada (and thus in the MA), there are more than 20,000 industrial jobs. 
An active non-agricultural population in the area equal to or greater than $66 \%$. In the MA only $7.1 \%$ of the workforce is involved in farming activities (INE, 2009).

Gross population density exceeding $100 \mathbf{~ h a b} / \mathbf{k m}^{2}$. The metropolitan area of Granada has a population density of $584 \mathrm{hab} / \mathrm{km}^{2}$.

Interrelatedness. The MA of Granada forms a continuous area. The main urban nucleus is related to more peripheral population centers by direct contact or through municipalities that fulfill the preceding conditions.

Fernández Avidad (1997) concludes that the MA of Granada is composed of 42 municipalities, although he restricts the area to populated territorial fragments instead of expanding it to include the entire area.

Consequently, this clearly points to the existence of an MA in Granada. This area has gradually appeared as a large urban nucleus in which other radial areas are integrated. Other crucial elements are its geographical location and its functional relationship with the other municipalities of the metropolitan area, regarding employment, transportation, and commerce. The following section describes the methodology used to analyze the growth of this area.

\section{Methodology}

For the analysis of urban growth in the MA of Granada, the following sources were used to create a map of this area:

Topographic maps (auxiliary material)

Topographic Map of Andalusia (1995) 1:10,000 (Raster mosaic)

Topographic Map of Andalusia (1998) 1:10,000 (Vector)

Topographic Map of Andalusia (2001) 1:10,000 (Vector). (ideAndalucía) http://www.ideandalucia.es/\#o1.

Topographic Map of Andalusia (2005) 1:100,000 (Vector). (ideAndalucía)

Aerial photographs and orthophotos (main material in the study)

1956. Set of black and white orthophotos at scale 1:33,000 and resolution of $1 \mathrm{~m}$. (ideAndalucía) produced by a U.S.A.F photogrammetric flight over Spanish territory

1978. Aerial Photography for Agriculture

1984. CNIG Aerial Photography

1994. Aerial photography made by the Junta Andalucía

2001. Aerial photography made by the Junta Andalucía

2007. Colour digital orthophoto of Spain, generated by a digital flight with a $0.90 \mathrm{~m}$ geometric resolution, Infrared RGB data at scale 1: 10,000. (ideAndalucía).

Other sources

Corine Land Cover

http://www.idee.es/clientesIGN/corineClient/index.html?lang=ES

Application of data regarding land use and geographic relief (IDEAndalucia)

Based on this information, the urban metropolitan area was digitized with a GIS software application for each year with available aerial photographs or orthophotographs (1956, 1978, 1984, 1994, 2001 and 2007). The following section presents the maps thus obtained. It also includes a table that summarizes the increase in built-up land in each location, and provides percentage graphs that justify the growth of the urban area in graphical and numerical form.

\section{Results}

In 1956-2007 there was an 84\% increase in the built-up land in Granada and its metropolitan area (see Figures 2 and 3). This was also accompanied by a corresponding growth of the urban population. In fact, in 1956-1978, 32 municipalities experienced an increase in built-up land of more than $30 \%$. The percentages for each town were the following:

(32\%): La Zubia

(40-50\%): Peligros, Monachil, Granada, Cijuela, Las Gabias, Güevéjar, Pulianas, and Fuente Vaqueros 
(50-80\%): Cúllar Vega, Albolote, Chauchina, Maracena, Armilla, Santa Fe, Dilar, Cájar, Otura, Churriana de la Vega, Jun, Viznar, Alfacar, Pinos Genil, Pinos Puente, Vegas del Genil, and Láchar (over 80\%): Huétor-Vega, Gójar, Cenes de la Vega, Alhendín, Ogíjares, and Atarfe.

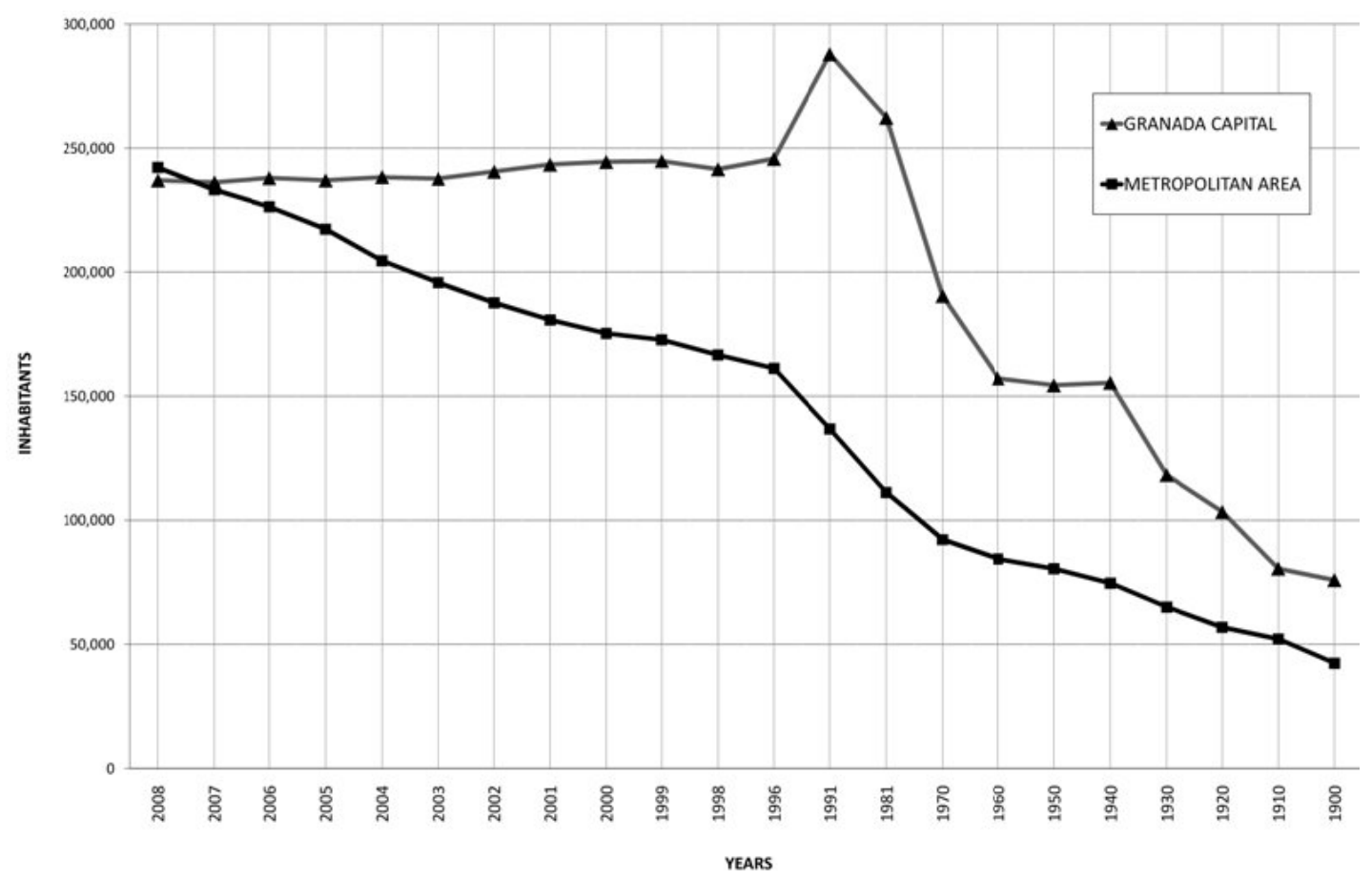

Figure 2. Evolution of the population in Granada city and towns nearby (Source: INE, 2009)

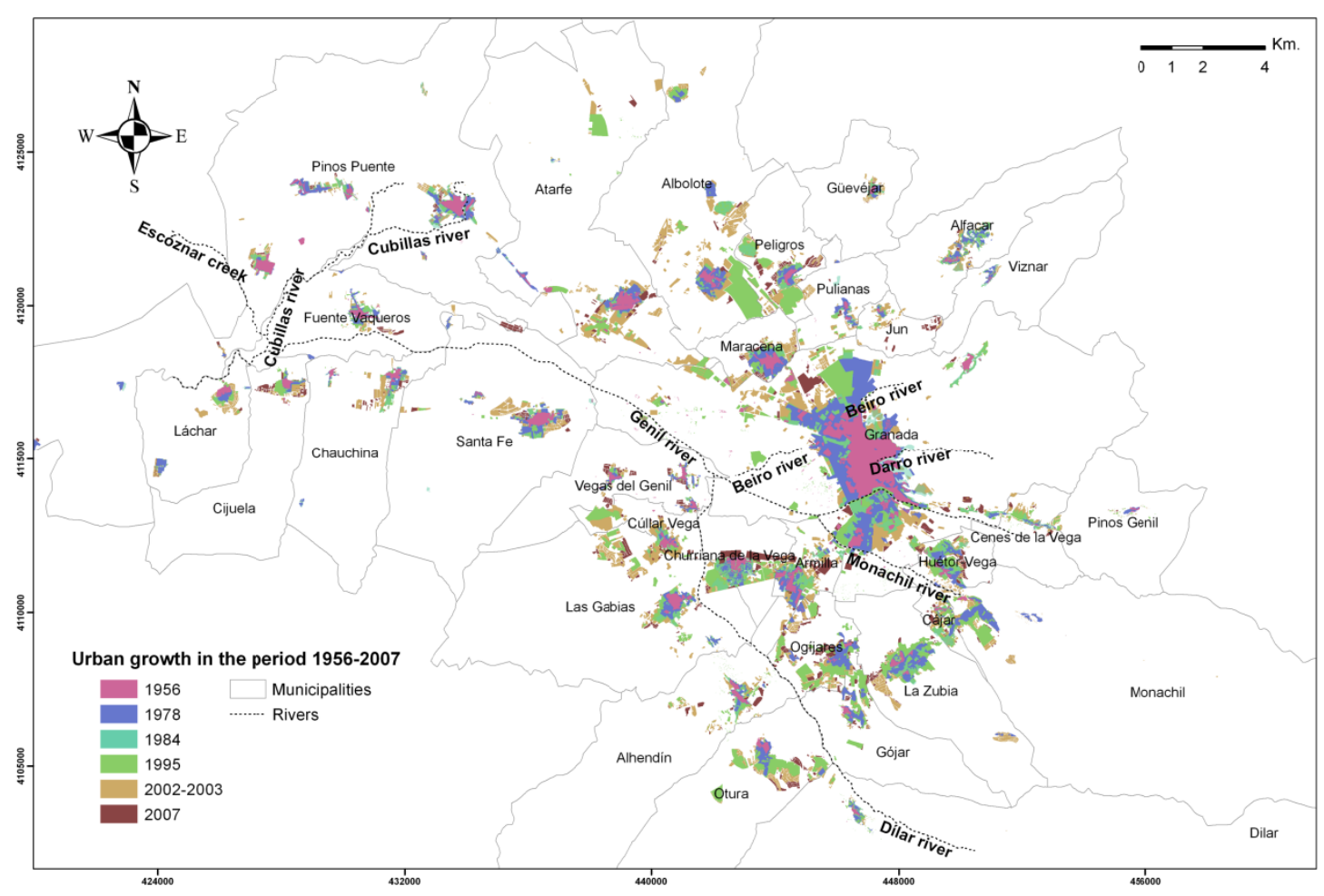

Figure 3. Urban growth in Granada and Metropolitan Area in the period 1956-2007 
Regarding population growth, in 1970 the MA of Granada began to have a considerably greater number of inhabitants. This coincided with an enormous increase in built-up land. For example, in 1978 there was 57\% more built-up land than in 1956 .

\subsection{Case Studies}

The case studies presented in this paper focus on three towns in the west of Granada, Atarfe, Albolote, and Fuente Vaqueros, as well as one town in the south, Churriana de la Vega. Also included is La Chana (a district in the northwestern part of the city of Granada). The detailed maps, tables, and graphical summary that follow clearly reflect and justify the remarkable urban growth of the area, in which various conurbation processes can be observed.

Fuente Vaqueros (Figures 4 and 5) experienced a radial growth arising from the annexation of buildings that existed in 1956. This growth pattern runs parallel to the main roads (GR-NO-33, GR-NO-14, GR-NO-13) that start from the central plaza of the town (Plaza del Doctor Pareja). The entire area has an elongated shape, widening at the center. The direction of expansion is from NNW to SSE. The S sector has a hydrological boundary, the Genil River, which is the main river in La Vega of Granada. This village is in a dangerous zone taking into account the behavior of soil in seismic conditions, there are phenomenon of liquefaction and densification (Valverde-Palacios, 2010); as a result, the best direction of growth is to NNW instead of SSE.

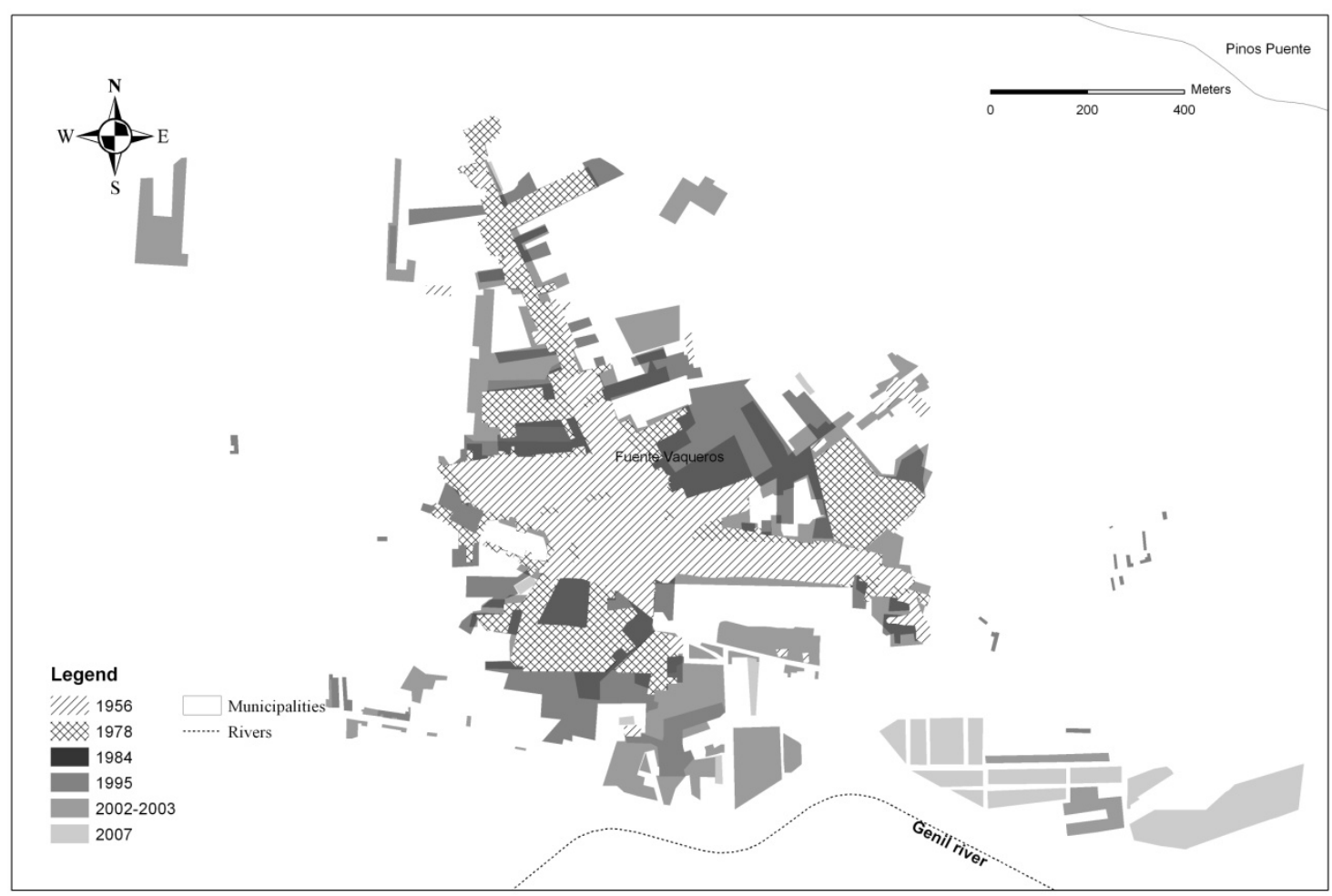

Figure 4. Evolution of urban growth in Fuente Vaqueros for the period 1956-2007 


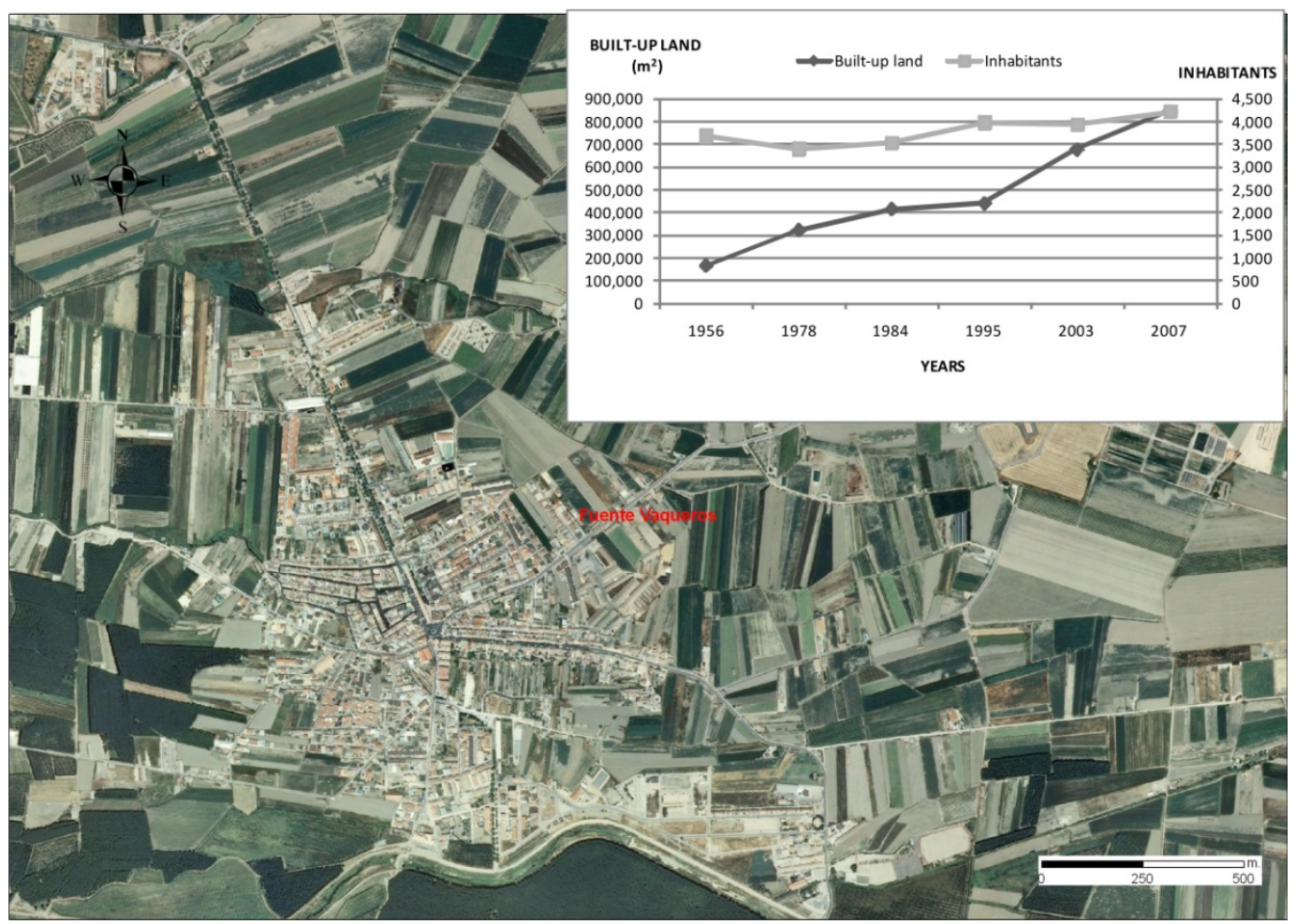

Figure 5. Fuente Vaqueros orthoimage for the year 2007 (source: IDEAndalucia. Junta de Andalucía). Graph of the evolution of urban growth and population for the period 1956-2007

In 1956-1978, the built-up soil in Fuente Vaqueros doubled, whereas in 1978-1984, it increased 22\%. Subsequently, growth remained constant at 6\% until 1995-2003, when it rose 34.9\%. In 2003-2007, built-up soil increased 20\%. Therefore, in the entire period from 1956 to 2007, Fuentevaqueros experienced an $80 \%$ increase in built-up land from $16 \mathrm{Ha}$ to approximately $85 \mathrm{Ha}$. This increase was not accompanied by population growth since from 1950 to 2007, the population only increased by 526 inhabitants. The reason for the spectacular boom in built-up land with no significant population growth is that many of the new buildings were either second residences or factory installations in industrial parks.

Atarfe and Albolote (Figures 6-9) follow a model of multiple cores, which branch out from buildings that existed in 1956. In the case of Atarfe, growth is adjacent to the NE area, and in the case of Albolote, it is adjacent to the $\mathrm{N}-\mathrm{S}$ and E-W areas. In addition, new population centers sprung up around existing buildings in the SW and WNW sectors of the towns. These growth patterns were further strengthened and consolidated by the important increase of built-up land in an important industrial park. Along with the industrial installations in Albolote-Peligros, both parks constitute an important link to the city Granada. Regarding relative growth, in 1956-1978, built-up land increased 40\% in Atarfe and 70\% in Albolote. In 1978-1984, even with the construction of housing developments, growth was slower in both towns (13.8\% in Atarfe and $15.4 \%$ in Albolote). In 1984-1995 and 1995-2003, growth soared again because of the construction of industrial parks and housing developments (45\% in Atarfe and 62\% in Albolote), However, in 2003-2007, construction activity slowed significantly (7.2\% in Atarfe and 3.1\% in Albolote). The direction of growth is not the best in the case of Atarfe. In fact, the most suitable direction is SE and ESE, considering the effects of an earthquake in the soil (liquefaction). 


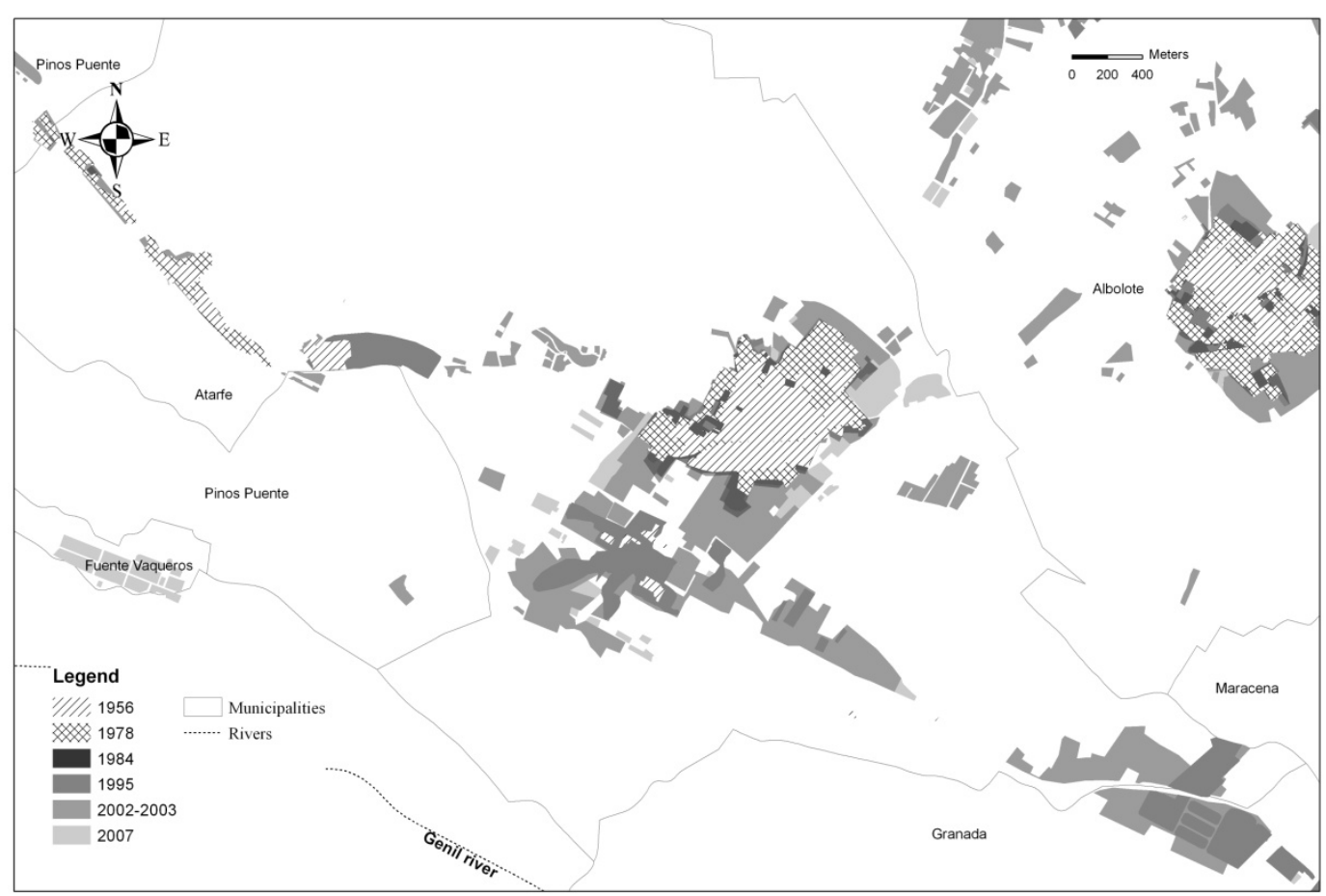

Figure 6. Evolution of urban growth in Atarfe for the period 1956-2007

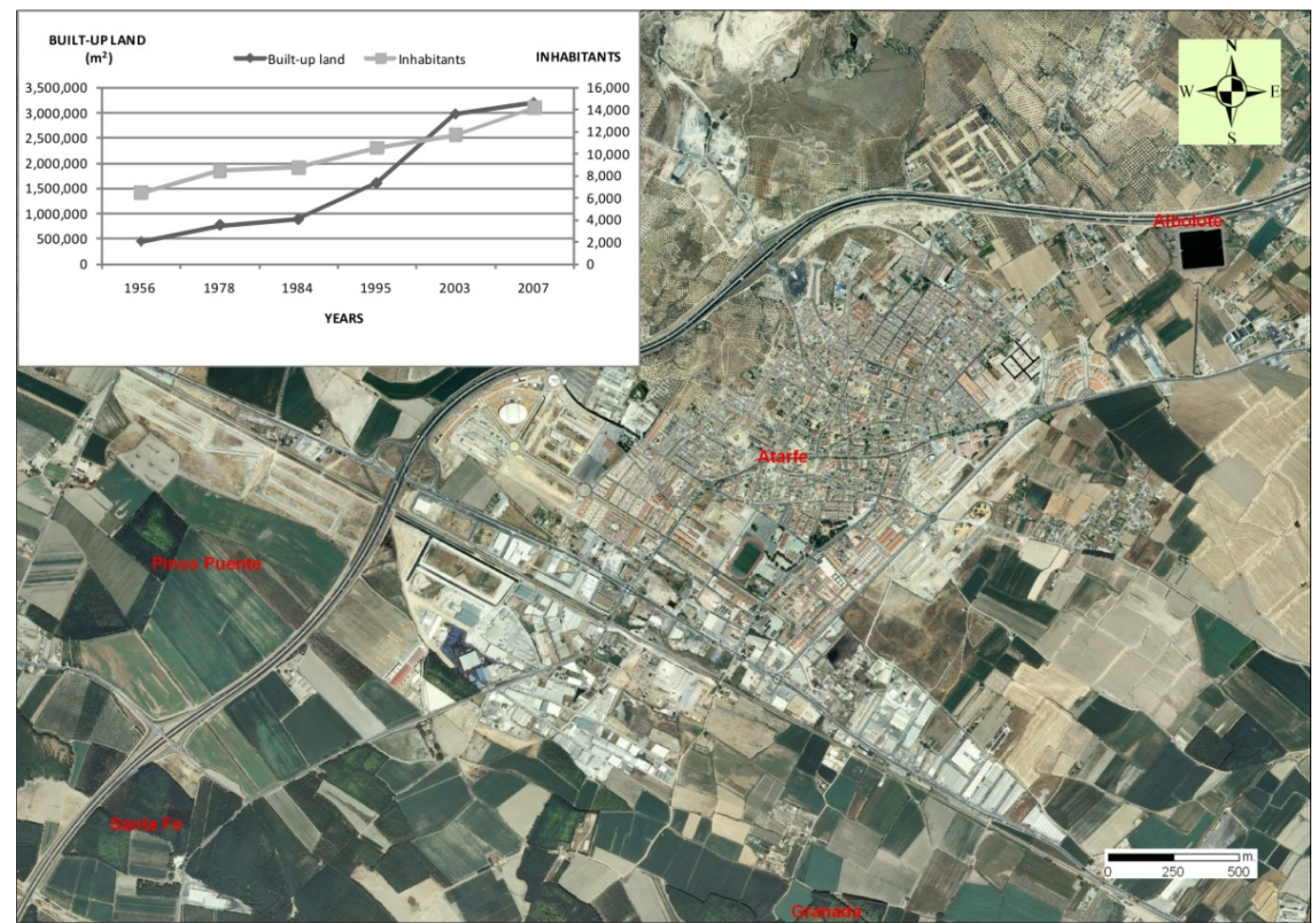

Figure 7. Atarfe orthoimage for the year 2007 (source: IDEAndalucia. Junta de Andalucía). Graph of the evolution of urban growth and population for the period 1956-2007 


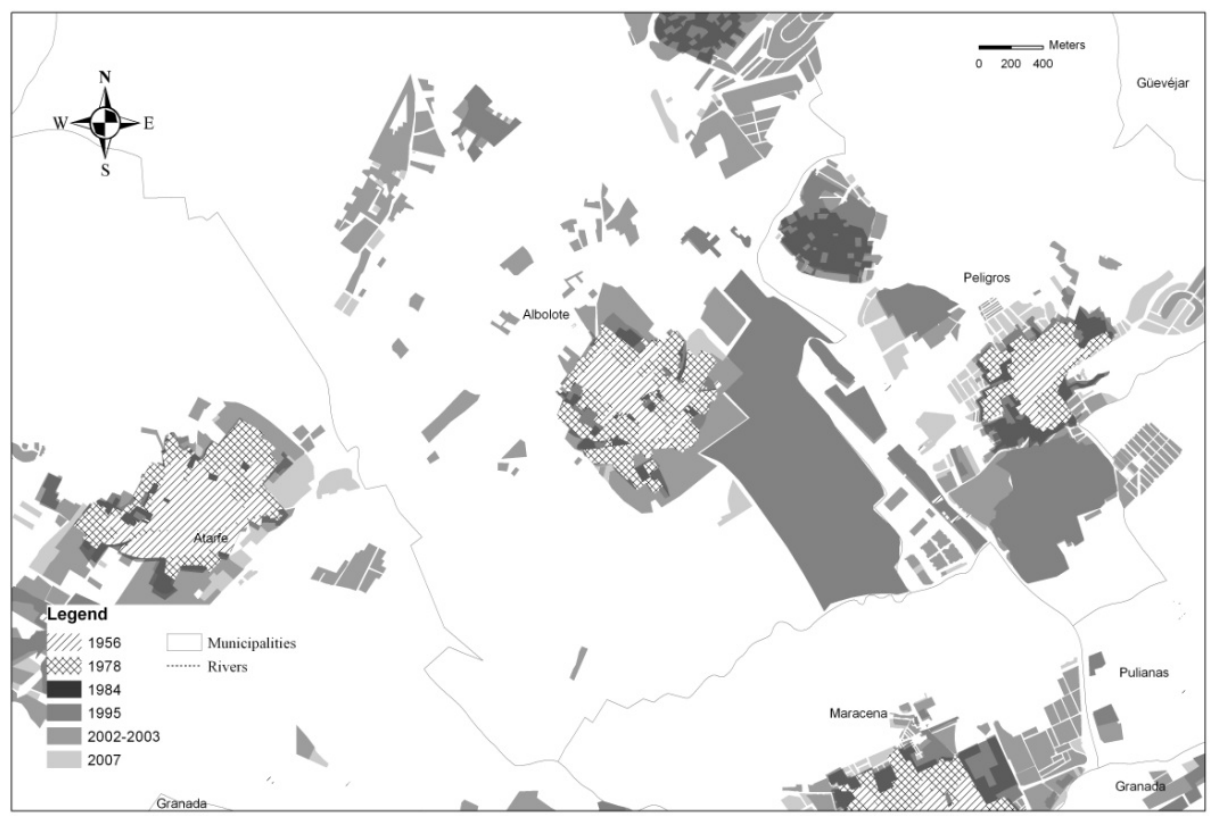

Figure 8. Evolution of urban growth in Albolote for the period 1956-2007

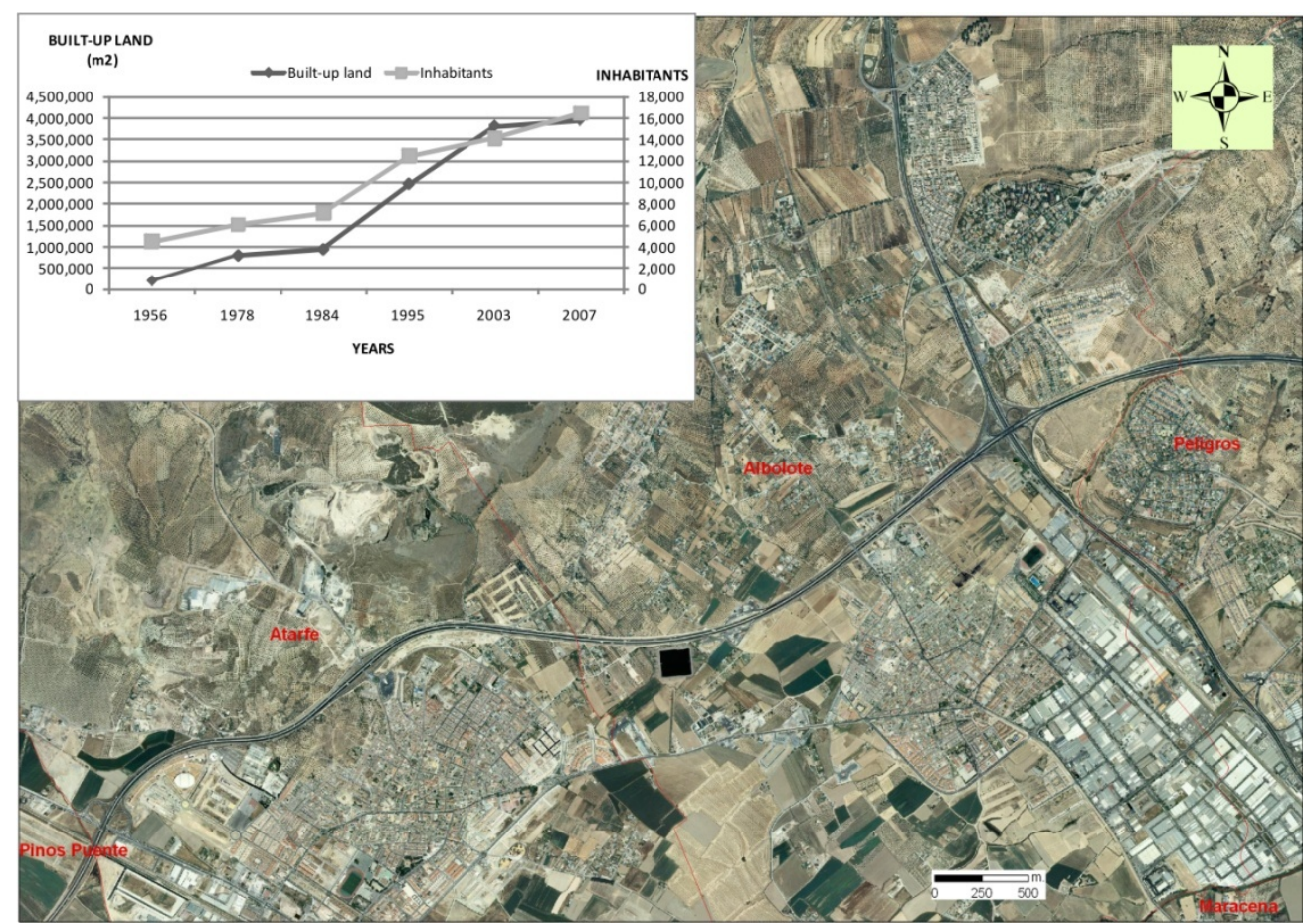

Figure 9. Albolote orthoimage for the year 2007 (source: IDEAndalucia. Junta de Andalucía). Graph of the evolution of urban growth and population for the period 1956-2007

The proximity of these towns to the city of Granada and their lower housing costs led to a population increase in both municipalities. According to the census figures of 1995-2007, the population of Atarfe increased by 7,689 inhabitants, and the population of Albolote by 11,963 inhabitants. These new residents occupied the newly built-up land, which increased by $86 \%$ during the same period. Atarfe experienced an increase in built-up land from $44 \mathrm{Ha}$ to about $320 \mathrm{Ha}$, whereas Albolote experienced an increase of $18 \mathrm{Ha}$ to $390 \mathrm{Ha}$. In this respect, Atarfe has become a major population nucleus for the first home of the population in the $\mathrm{N}$ sector of the metropolitan area. 
The district of La Chana (Figures 11 and 12), in the city of Granada has also grown significantly. That is the result of Granada's expansion into the NW sector. This district is now linked to the town of Maracena town by the Cerrillo de Maracena, which reflects still another conurbation process. Built-up land in La Chana has increased by $90 \%$, soaring from $17 \mathrm{Ha}$ to approximately $175 \mathrm{Ha}$. Granada thus experienced a total increase of 1202 hectares in 1956-2007. Not surprisingly, the lower building costs in the surrounding areas near Granada have led to the exodus of the population towards these new urban nuclei. Accordingly, the population of the city of Granada has thus been decreasing since the 1980s. In this case and in Churriana de la Vega, there isn't any problem with the behavior of the soil in dynamic condition.

Churriana de la Vega (Figures 12 and 13) reflects a longitudinal growth model expanding in an EW direction. This conurbation process has joined Churriana de la Vega to the town of Armilla, and practically to the city of Granada. A similar growth pattern is also reflected in the towns of Ogijares, La Zubia, Gójar, and Cájar, where the boundaries of one municipality now seamlessly blend into those of another. The Armilla Air Force Base is one of the boundaries of Churriana de la Vega that limits urban growth to the south. Since the town has exhausted urbanizable land in the $\mathrm{E}$ and $\mathrm{W}$ sectors, its only alternative is to expand north into La Vega. At least for now, the partial urban plans only envisage single-family town houses. In 1956-2007, built-up land in Churriana de la Vega increased by $85.5 \%$ (from $15 \mathrm{Ha}$ to $170 \mathrm{Ha}$ ). There was also a population growth of $70 \%$. Along with Armilla, Ogíjares, La Zubia, Gójar and Cájar, Churriana de la Vega has become a new population nucleus for those building their first home in the $\mathrm{S}$ sector of the metropolitan area.

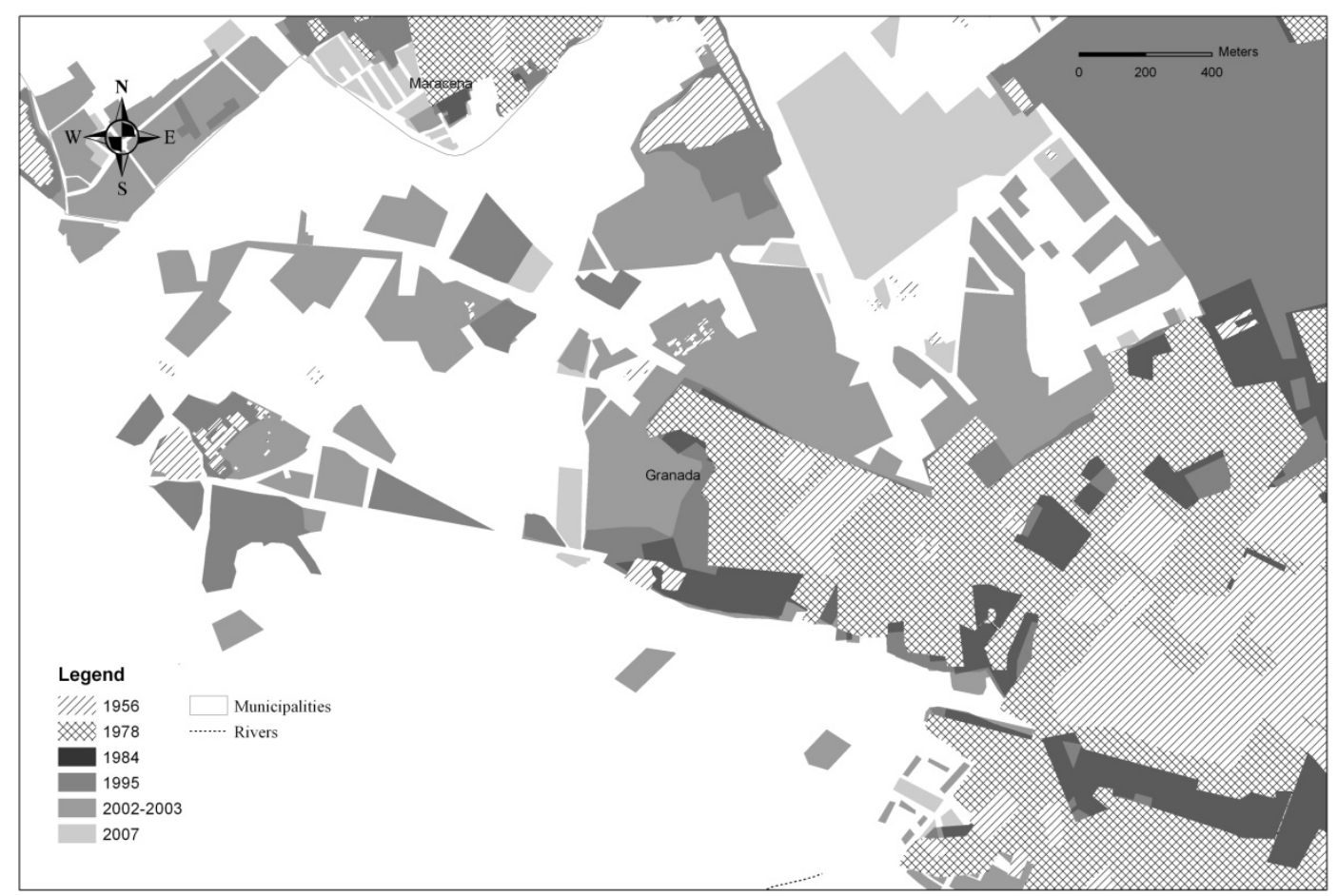

Figure 10. Evolution of urban growth in district of La Chana (city of Granada) for the period 1956-2007 


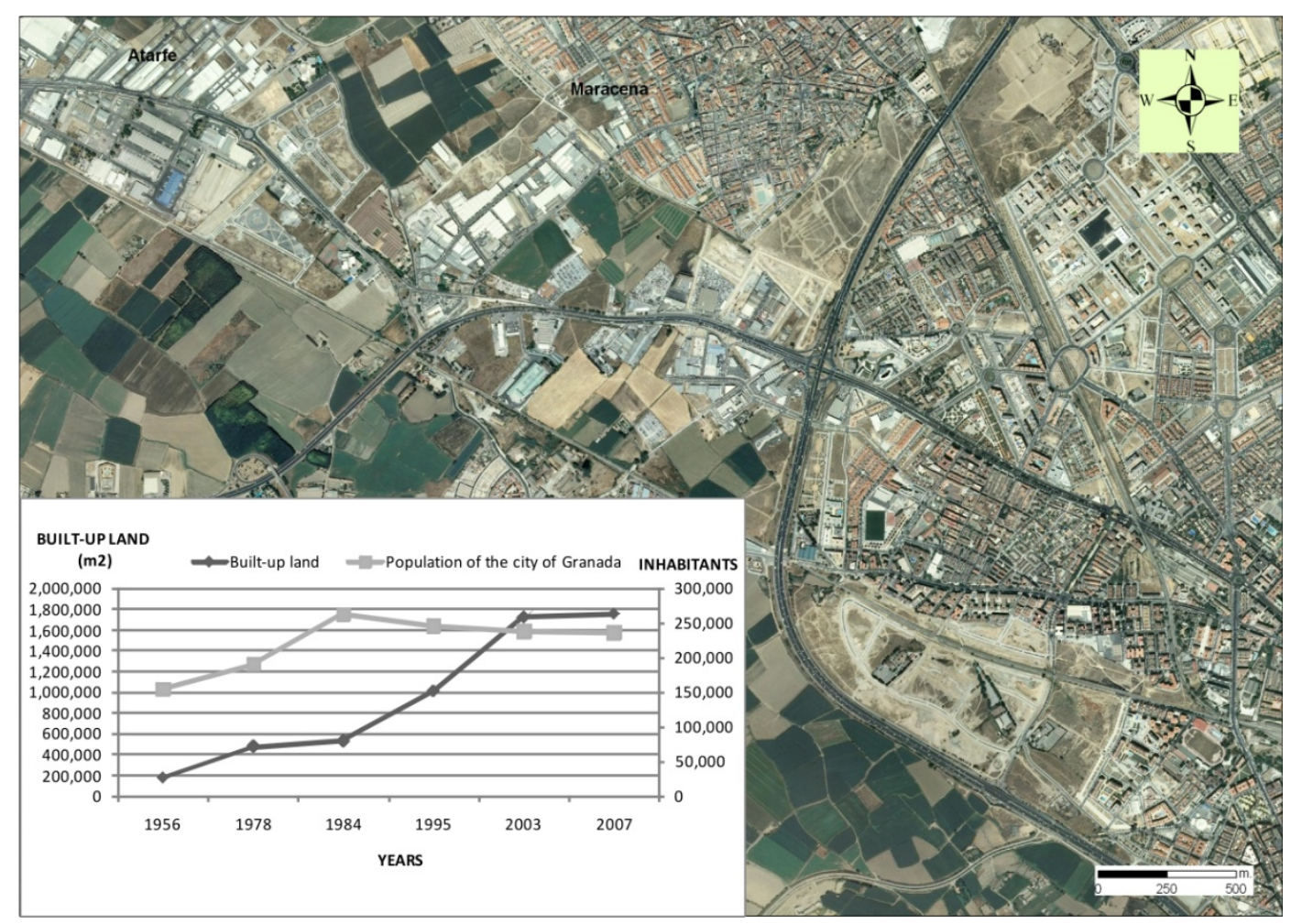

Figure 11. District of La Chana (city of Granada) orthoimage for the year 2007 (source: IDEAndalucia. Junta de Andalucía). Graph of the evolution of urban growth and population for the period 1956-2007

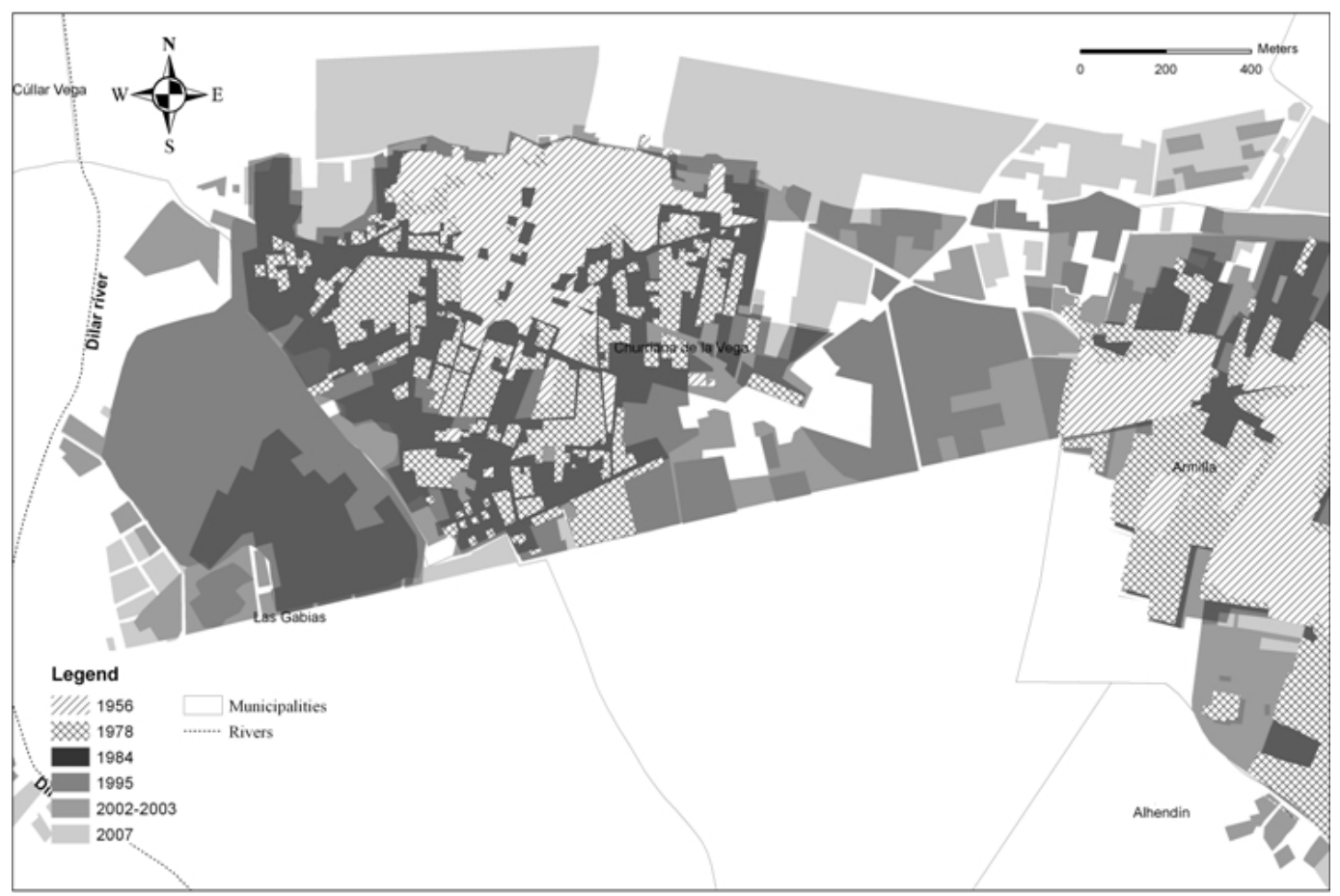

Figure 12. Evolution of urban growth in Churriana de la Vega for the period 1956-2007 


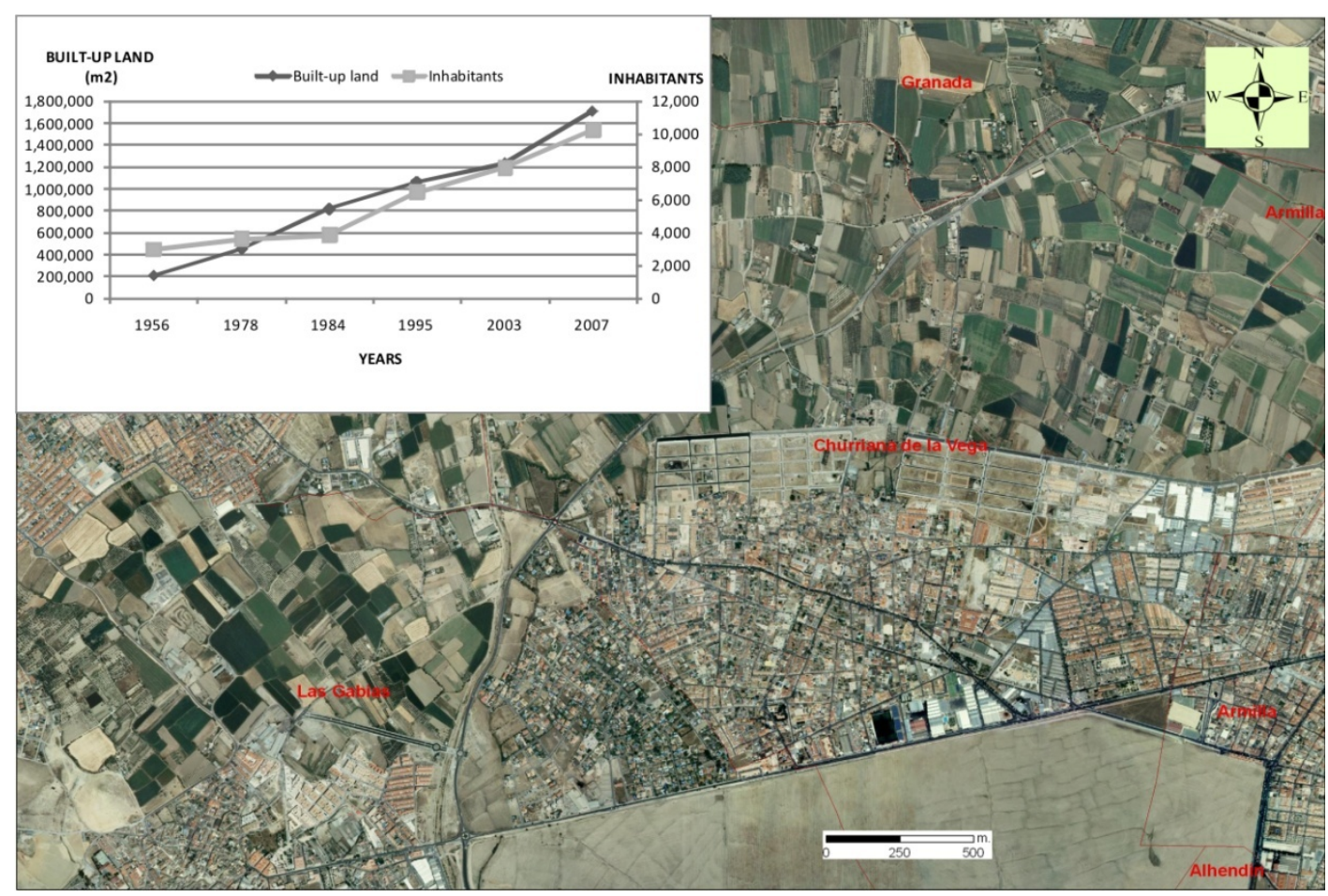

Figure 13. Churriana de la Vega orthoimage for the year 2007 (source: IDEAndalucia. Junta de Andalucía). Graph of the evolution of urban growth and population for the period 1956-2007

\section{Conclusions}

In the last fifty years, the population of Granada and its metropolitan area has doubled. This has led to an increase in built-up land of approximately 4650 ha. Furthermore, the areas that have experienced the largest growth in population and built-up land are located less than $15 \mathrm{~km}$ from the city.

In 1956-2007 there was an 84\% increase in built-up land in Granada and its metropolitan area. In fact, in 1956-1978, 32 municipalities experienced an increase in built-up land of more than $30 \%$. This was also accompanied by a corresponding urban population growth, which began in 1970 and lasted throughout the period.

Since the increase in built-up land and number of inhabitants has occurred in a moderate seismic hazard zone (NCSE-02), the risk from seismic events has become greater. This is despite the fact that buildings are now less vulnerable to earthquakes because of technical advances in construction, new materials, energy dissipation, and regulations to minimize and mitigate construction vulnerability.

The detailed study of urban growth in Albolote, Atarfe, Fuente Vaqueros, Churriana de la Vega and La Chana, together with analysis of soil dynamic behavior has established the optimal direction for the expansion of these municipalities (Valverde-Palacios, 2010). It is also important to consider urban growth scenarios as presented by Aguilera et al. (2011).

Finally, it is essential to take into account the seismic effects on the soil to plan urban growth.

This study shows that in some cases the growth directions are not correct, like in Fuente Vaqueros and Atarfe.

\section{References}

Aguilera, B. F., Plata, R. W., Bosque, S. J., \& Gómez, D. M. (2009). Diseño y simulación de escenarios de demanda de suelo urbano en ámbitos metropolitanos. Revista Internacional Sostenibilidad, Tecnologíay Humanismo, 4, 57-80.

Aguilera, F., Valenzuela, L. M., \& Botequilha-Leitão, A. (2011). Landscape metrics in the analysis of urban land use patterns: A case study in a spanish metropolitan area. Landscape and Urban Planning, 99(3-4), 226-238. http://dx.doi.org/10.1016/j.landurbplan.2010.10.004 
Almoguera, S. M., \& Ríos, V. M. T. (2008). Transformación de las áreas metropolitanas desde una perspectiva comparada: Sevilla y Gran Santiago de Chile. Implicaciones y respuestas desde la política de ordenación del territorio en la última década. Revista electrónica de Geografía y Ciencias Sociales, XII (270).

Berry, J. B., Gohhen, P. G., \& Goldstein, H. (1968). Metropolitan area definition: a reevaluation of concept and statistical practice. Washington D.C.: U.S. Census Bureau.

Boix, D. R. (2007). Concepto y delimitación de áreas metropolitanas: una aplicación a las áreas metropolitanas de España. Seminario Las grandes áreas metropolitanas españolas en una perspectiva comparada. Centro de Estudios Andaluces. Junta de Andalucía. Seville. http://urban.uab.es/references/2007/07002.pdf

Cañete, P. J. A., Lozano, M. J. M., \& Sáenz, L. M. (2005). Cambios demográficos en la aglomeración urbana de Granada y Plan de Ordenación del territorio. Cuadernos Geográficos, 36, 275-289.

Conde, F. (1999). Urbanismo y Ciudad en la aglomeración Urbana de Granada. Culturas e identidades urbanas. Sevilla: Junta de Andalucía. Consejería de Obras Públicas y Transportes. Empresa Pública del Suelo de Andalucía.

Cooke, T., \& Marchant, S. (2006). The changing intrametropolitan location of high-poverty neighbourhoods in the US, 1990-2000. Urban Studies, 43(11), 1971-1989. http://dx.doi.org/10.1080/00420980600897818

Coombes, M. G. (1978). Towards a more rational consideration of census areal units: daily urban systems in Britain. Environment and Planning, 10, 1179-1185. http://dx.doi.org/10.1068/a101179

Davis, K. (1967). La urbanización de la población humana. In Scientific American: La Ciudad, Spanish translation, Madrid, Alianza Editorial.

De Esteban, A. (1981). Las áreas metropolitanas en España: Un análisis ecológico. Madrid: Centro de Investigaciones sociológicas. Colección Monografías.

Feria Toribio, J. M., Susino Arbucias, J., Casado Díaz, J. M., \& Sardhina de Oliveira, G. (2005). Movilidad por razón de Trabajo en Andalucía. Sevilla: Instituto de Estadística de Andalucía.

Fernández, A. Á. (1997). Estructura de un espacio metropolitano. PhD thesis defended at the E.T.S. de Arquitectura, Granada: University Granada (Spain).

Font, A. (1972). La delimitación de las áreas metropolitanas: el caso de Barcelona. Cuadernos de Arquitecturay Urbanismo, 87.

Fox, K. A. (1964). Integrating National and Regional Models for Economic Stabilization and Growth. University of Pittsburgh.

Friedman, J., \& Miller, J. (1965). The urban field. Journal of the American Institute of Planners, 31, 312-320. http://dx.doi.org/10.1080/01944366508978185

Gohhen, P. G. (1971). Metropolitan area definition: re-evaluation of concept and statistical practice. Internal structure of the city reading on espace and enviroment. Toronto: Oxford University Press.

Hall, P., \& Hay, D. (1980). Growth centers in the Urban Europ System. London: Educational Books.

Instituto Nacional de Estadística. (2009). Retrieved February 12, 2009, from http://www.ine.es.

Junta de A., Consejería, de O., \& Públicas, Y. T. (1999). Plan de Ordenación del Territorio de Aglomeración Urbana de Granada (POTAUG). Granada: Consejería de Obras Públicas y Transportes. Dirección General de Ordenación del Territorio y Urbanismo.

Menor, T. J. (1997). Transformaciones recientes en la Organización territorial de la Vega de Granada: del espacio agrario tradicional a la aglomeración urbana actual. Estudios Regionales, 48, 189-214.

Ministerio, de la V. (1960). Áreas Metropolitanas de España en 1960. Madrid: Dirección General de Urbanismo. Ministerio de la Vivienda.

Nunes, I., \& Alonso, J. (1986). Aproximació a l'estructura de l'area metropolitana de Barcelona: les estructures d'intensitat diària. Documents d'Anàlisi Geogràfica, 8-9, 71-90.

Rozenfeld, H. D., Rybski, D., Andrade Jr., J. S., Batty, M., Stanley, H. E., \& Makse, H. A. (2008). Laws of population growth. Proceedings of the National Academy of Sciences of the United States of America, 105(48), 18702-18707. http://dx.doi.org/10.1080/01944366508978185

Sánchez, G. D. (2005). El proceso de envejecimiento demográfico en Granada y su Área Metropolitana. Cuadernos Geográficos, 37, 185-199. 
Serra, J. (1991). La ciutat metropolitana delimitacions, desconcentracions, desequilibris. Barcelona: Institut d'Estudis Metropolitans de Barcelona.

Storper, M. (2010). Why Does a City Grow? Specialisation, Human Capital or Institutions? Urban Studies, 47(10), 2027-2050. http://dx.doi.org/10.1177/0042098009359957

Unwin, D. J. (1996). GIS, spatial analysis and spatial statistics. Progress in Human Geography, $20(4), 540-551$. http://dx.doi.org/10.1177/030913259602000408

Valverde, P. I. (2010). Cimentaciones de edificios en condiciones estáticas y dinámicas. Casos de estudio al W de la ciudad de Granada. PhD Thesis defended at the University of Granada (Spain). http://0-hera.ugr.es.adrastea.ugr.es/tesisugr/18877485.pdf

Van Geffen, J. (2003). Metropolitan Statistical Area Changes. Texas Labor Market. 